\title{
Çocukluk Dönemi Din Eğitimine Gelişimsel Bir Bakış Açısı
}

\author{
MUSTAFA KÖYLÜ \\ CEMIL ORUC
}

\section{Özet}

Gelişimsel din eğitimi, psikoloji ve eğitim bilimleri alanlarındaki gelişmeler çerçevesinde şekillenmiş bir eğitim faaliyetidir. Bu çalışmada tarihsel süreç içerisinde psikoloji ve pedagojideki gelişmeler ve teoriler bu alandaki öncü şahsiyetler üzerinden sunulmuştur. Bu çerçevede çalışmamızda psikoloji ve eğitim bilimlerindeki çalışmaların verilerinden hareket eden din eğitimi çalışmalarının metodolojisi, ilkeleri ve problemleri incelenmiştir. Çalışmamız yöntem olarak öncelikle genel gelişimde kuram geliştiren şahsiyetlerin temel görüşlerini ele almış, ardından bunlar esas alınarak geliştirilen dini gelişim ve din eğitimi teorilerini konu edinmiştir. Çalışmamız literatür tarama ve doküman incelemesine dayanmaktadır. Konuyla ilgili birincil kaynaklar incelenmiş ve bunların din eğitimine etkileri farklı alan araştırmaları ile birlikte değerlendirilmiştir. Sonuç olarak, din eğitiminin gelişim teorileriyle birlikte ele alınması ve bilimsel ölçütler çerçevesinde programlanması gerektiği görülmüştür. Böyle bir din eğitimi faaliyetinin birçok yönüyle olumlu katkılarının olacağı açıktır. Bununla birlikte dini gelişim ve eğitim konusunu salt bilimsel ölçütlerle sınırlamanın maneviyat ve kutsallık gibi din eğitiminin önemli bileşenlerini ihmal etmek gibi bir sorunla karşı karşıya olduğunu, bunların ayrıca ele alınması gerektiğini belirtmemiz gerekir.

Anahtar kelimeler: Çocukluk dönemi, din eğitimi, dini gelişim, maneviyat

- ARASTIRMA MAKALESI-

MUSTAFA KÖYLÜ, mkoylu@omu.edu.tr Ondokuz Mayıs Üniversitesi, İlahiyat Fakültesinde, Din Eğitimi ORCiD https://orcid.org/0000-0002-3754-0751

Çocuk ve Medeniyet
CEMIL ORUC, cemil.oruc@inonu.edu.tr İnönü Üniversitesi, İlahiyat Fakültesi, Din Eğitimi ORCiD https://orcid.org/0000-0002-9870-8597

Gelis tarihi: 03.11.2021 • Kabul tarihi: 02.12.2021 doi: https://doi.org/10.47646/CMD.2021.254 


\begin{abstract}
Developmental religious education is an educational activity shaped within the framework of developments in the fields of psychology and educational sciences. In our study, developments and theories in the field of psychology and pedagogy in the historical process are presented through the leading figures in this field. Studies in these areas have been adapted to religious development and religious education. In this context, in our study, the methodology, principles and problems of religious education studies, which are based on the data of studies in psychology and educational sciences, were examined. As a method, our study first examined the basic views of the people who developed theories in general development, and then the religious development and religious education theories developed on the basis of these. Our study is based on literature and document review. The primary sources related to the subject were examined and their effects on religious education were evaluated together with different field studies. As a result, it has been seen that religious education should be considered together with developmental theories and should be programmed within the framework of scientific criteria. It is clear that such a religious education activity will have positive contributions in many aspects. However, it should be noted that limiting the subject of religious development and education to purely scientific criteria is faced with the problem of neglecting important components of religious education such as spirituality and holiness.
\end{abstract}

Keywords: Childhood, religious education, religious development, spirituality

\title{
Giriş
}

Dini gelişim ve eğitim konusu son yılların önemli çalışma alanlarından biri haline gelmiştir. Farklı disiplinler tarafından yapılan çalışmalar birçok açıdan din ve maneviyatın insan yaşamındaki yerini tartışmaya açmıştır. Dini gelişim çalışmaları, bir yandan radikal hareketler, şiddet ve bir kısım psikolojik rahatsızlıklarla ilişkilendirilirken, diğer taraftan özellikle ABD ve bazı Batı ülkelerinde gelişim psikolojisinin önemli bir çalışma alanı olarak görülmüş ve bu çalışmalar neticesinde geliştirilen dini gelişime katkı sağlayan yöntemler ve yeni öğretim biçimine dönük örnekler ders kitaplarında yer bulmaya başlamıştır (Santrock, 2009; Boyatzis, 2014). Bu çerçevede konuyu Huristiyanlık ekseninde değerlendiren Wright (1953), geçmişte dinin Kilise etrafında konumlandığı, ancak günümüzde dinin artık her yerde olduğunu ifade eder. Bütün bu gelişmeler aslında uzun süredir konuşulan ve bilimsel açıdan tartışılan birçok konuyu yeniden gündeme getirmiştir: Bilimsel ölçütler çerçevesinde gelişime pozitif katkı sağlayacak bir dini gelişim ve din eğitimi modeli geliştirilebilir mi? 
Son dönemdeki birçok ulusal ve uluslararası gelişme, dinin insani gelişim süreçleri ile uyumunu ve bu uyumdan ortaya çıkacak geniş ve verimli alanı işaret etmektedir. Bu anlamda din eğitimi salt bir bilgi aktarımından öteye geçmek durumundadır ve bunun için gelişim psikolojisi verileri önemli bir kaynak oluşturur. Bu tür arayışlar günümüzün temel bazı problemleri için çözümler geliştirme potansiyeline sahiptir (Atik, 2019). Gelişim psikolojisi verileri incelendiğinde yukarıdaki sorulara cevaplar verildiği ve gelişim konusundaki tartışmaların oldukça kapsamlı bir şekilde sürdügü görülür (Rousseau, 2019; Piaget, 2015; Erikson, 1963; Allport, 1962). Tarihsel olarak dini gelişim ve eğitim konusu her inanç sisteminde tartışılmış ve bu konuda birçok yaklaşım geliştirilmiştir. Bu noktada özellikle dini gelişim ve eğitimin genel eğitim ve psikoloji çalışmaları ile birlikte ele alındığı araştırmalar öne çıkmaktadır. Buna göre çocukluk, ergenlik, gençlik ve yetişkinlik dönemlerinin her birinin ayrı gelişim dönemleri olarak sınıflandırılması ve söz konusu dönemlerin gelişim görevlerine göre din eğitimi içeriklerinin belirlenmesi gerekmektedir (Schweitzer, 2006; Ashton, 2000; Fowler, 1991; Elkind, 1970; Goldman, 1964). Gelişimsel bir din eğitimi yaklaşımı da ancak bu çerçevede düşünülmelidir.

Çalışmamızda, dini gelişim, psikoloji ve eğitim bilimlerindeki teorik temeller çerçevesinde ele alınmıştır. Bu çerçevede ilk olarak dini gelişim ve eğitim konularının kısa bir tarihsel arkaplanı verilmiştir. Ardından konunun gelişim psikolojisi açısından öne çıkan bazı temsilcileri tarafından ele alınış şekli incelenmiştir. Çalışmamızda dini doğrudan şiddet veya patoloji ile ilişkilendiren teorisyenlere yer verilmemiştir. İkinci olarak, gelişim psikolojisi çalışmalarındaki metodolojinin dini gelişim ve eğitim çalışmalarına uyarlanmasıyla sonuçlanan gelişimsel din eğitimi çalışmalarının temel yöntem ve prensipleri incelenmiştir. Burada doğrudan bir teori yerine, söz konusu çalışmaların genel değerlendirmesine yer verilmiştir. Üçüncü ve son olarak da, dini gelişim ve eğitimin bilimsel ölçütlerle gerçekleştirilmesinin muhtemel problemleri incelenmiştir.

\section{Gelişimsel Perspektif ve Din Eğitimi}

Eğitim tarihinde dinin gelişimsel olarak ve bilimsel yöntemlere göre ele alınmaya başlanması 18. ve 19. yüzyıllarda gerçekleşmiştir. Elbette bu durum, din ve gelişim konusunun yüzyıllar boyunca hiç incelenmediği anlamına da gelmez. Nitekim Nirvana'ya ulaşmak için neler yapılması gerektiğini öğütleyen inançlardan, Tanrı'ya yaklaşmak ve onunla bir bütün olmak için sistematik yöntemler geliştiren inançlara kadar insanlık tarihi ile eşdeğer birçok açıklama ve uygulama şekli daima olagelmiştir. Bütün bu 
açıklamalar aslında gelişimin en basit halinden oldukça karmaşık ve ileri düzeye nasıl ulaştığını ortaya koyar. Tarih boyunca birçok insan aslında kişinin yaşam boyunca gerçekleştirdiği dini gelişimi, algı ve tutumların dönüşümünü ve ilerlemesini anlamaya ve açıklamaya çalışmıştır. Ancak bunların gelişimsel ve bilimsel standartlarda yapılması yaklaşık 150 yıllık bir konudur.

Günümüzdeki dini gelişim çalışmalarının tarihsel süreçteki karşılığı daha çok mistik düşüncelerdedir. Mistik öğretiler insanın olgunlaşma yolunda kat ettiği ve kat edeceği mesafeler üzerine kafa yormuş, bu çerçevede bir kısmı bugüne de ulaşan bazı klasik eserler ortaya konulmuştur. Mistisizmin özellikle gelişim süreçlerini insanın olgunlaşması açısından belirli basamaklar halinde incelemesi ve bunu sistemleştirmesi günümüz dini gelişim çalışmaları ile benzerlik gösterir. Bu konuda gelişim teorileri ile mistik süreçleri karşılaştıran çalışmalar da yapılmıştır. Örneğin Ávilaılı Teresa'nın (1515-1582) mistik birliğe giden yedi yolunu, Jane Loevinger'in (1918-2018) ego gelişimi modeli ile karşılaştırmalı olarak inceleyen çalışmalarda etkileyici bir benzerlik olduğu da görülmüşsür (Meadow, 1992). Ancak söz konusu mistik yollar ve modern teorilerin birçok farklılaşan yönlerinin de olduğunu unutmamak gerekir. Çünkü her teori veya model kendi döneminin izlerini taşır.

İslam düşüncesinde ise gelişimsel süreçlerle ilgili ipuçları yine tasavvufta görülmektedir. Tasavvufta kişinin bazı aşamalardan geçtiği ve bu sürecin sonunda belirli bir olgunluk düzeyine ulaştığı varsayılır. Bu sistematik şema içerisinde kişi belirli terbiye yöntemleri aracılığıyla insani yönünü geliştirir ve kemale ulaşmayı hedefler. Bu süreç yaşam boyu devam eder. Kişi bu süreçte her dem yeniden doğmakta ve kendi varlığının şuuruna ermektedir. Bu anlamda tasavvufta bilinç dışı kişinin kurtulması gereken bir alan değil, Jung'un da ifade ettiği gibi kişinin mutlaka keşfetmesi gereken ve kendisi için de oldukça verimli bir alandır. Kısaca tasavvufta gelişim süreci salt bilişsel veya duyuşsal değil, varlığın bütünü ile ilgili ve özellikle bilinçdışını kapsayan bir çerçevede değerlendirilmiştir. Gazali (1058-1111) örneğinde olduğu gibi tasavvuf 'iyileştirme ve geliştirme' (Arasteh ve Sheikh, 2015) şeklinde ele alınmıştır.

İslam eğitim tarihinde günümüz anlamında gelişimsel bir din eğitimi yaklaşımını görmek zordur. Bununla birlikte örneğin Gazali'de olduğu gibi, gelişim konuları dönemine göre oldukça detaylı bir şekilde ele alınmıştır.

Çocuk ve Medeniyet 2021/2
Gazali gelişimi, 0-2 yaş dönemi için tufulet, 3-7 yaş dönemi için sabavet, 7-15 yaşları için mümeyyiz ve 15-40 yaş dönemi içinse ömrü'l-vasat şeklinde isimlendirmiştir ki bu isimlendirmeler büyük oranda dini literatür ile 
ilişkilidir. Bu dönem sınıflandırmalarında eğitim açısından her bir gelişim döneminin kendine mahsus özellikleri olduğunu ifade eder. Gazali’ye (2004, III, s.10) göre sabavet dönemindeki çocuk ve gençler mümeyyizlik dönemindekilerin halini bilmezler ve her bir dönemin bilgi elde etme kapasitesi farklıdır. Gazali (2004, I, s.130) bu dönemler ile ilgili olarak alma, anlama, inanma, yakîn ve tasdik şeklinde bir sürecin işlediğini ve bunlar için de belli gelişimsel süreçlerin yaşanması gerektiğini vurgular. Oluşturduğu sistemde 15'li yaşlar ise, olgunluğun ve toplumda bir şahıs olmanın başlangıcı olarak görülür. Bu yaşlarda insanın akli yetenekleri yüksek bir düzeye erişir. Daha önemlisi artık sorumluluk alma dönemi başlar.

Görüldüğü üzere tarihsel süreç içerisinde gelişim olgusu dini konularla ilişkili olarak farklı şekillerde işlenmiş ve bu konuda özellikle eğitim uygulamaları noktasında önemli bir literatür oluşmuştur. Ancak günümüzdeki bilimsel bakış açısı ile bakıldığında bunların sistematik bir gözlem, test etme, yordama gibi süreçlerle ilişkili olmadığı söylenebilir. Teorik olarak dini kaygılarla ortaya çıkan bu yaklaşımlar, önceden planlanmış bir sistematik içerisinde sunulmuş ve kişinin erginleşme sürecinde belirli yol ve yöntemler eşliğinde geliştirilmek istenmiştir.

Günümüzdeki anlamıla gelişim konuları ilk defa Jean-Jacques Rousseau (1712-1768)'nun çalışmalarında görülmektedir. Rousseau (2019), çocukların soyut ve sembolik din dilini anlamalarının mümkün olmadığını, Tanrı'yı yetişkinlerin teşvikiyle antropomorfik bir şekilde düşünmeleri sebebiyle yanlış veya eksik bir şekilde hayal ettiklerini belirtmiştir. Bütün bunlar Rousseau'yu ergenliğe kadar çocuklara din hakkında herhangi bir bilgi vermemek gerektiği sonucuna götürmüştür. Ona göre ergenlikten itibaren kişi kendi inancını oluşturabilir ve yetişkinlerin bu konuda yönlendirmelerden sakınması gerekir. Rousseau'nun bu konuda oldukça katı bir görüş benimsemesinde kendi döneminin dini inanç ve uygulamalarını ve Kilise'nin nüfuzunu hatırlamak gerekir. İlaveten Rousseau'nun kurumsal dini mi yoksa inancı mı kast ettiği de çok açık değildir. Ancak onun yapmış olduğu gelişim sınıflandırması, konunun bilimsel ölçütlere göre incelenmeye başlandığının ilk örneği olması açısından önemlidir.

Gelişimsel din eğitimi konusunda ilk önemli çalışmalar G. Stanley Hall (1846-1954) ile başlar. O, bireysel dini gelişimin insanlık türünün gelişimi ile benzerlik gösterdiğini savunur. Rousseau'nun belirttiği bilinçdışı dini gelişim ve antropomorfik Tanrı düşüncesi gibi konuları çoğu kez Hall de yöntem önerisinde bulunur. Ona göre çocukluk dönemi din eğitiminde Eski Ahit'e, ergenlik dönemi din eğitiminde ise Yeni Ahit'e yer vermek, gelişimsel 
açıdan daha uygundur. Bunun sebebi ise, çocukların daha yakın zamanda edinilmiş yolları benimsemeden önce daha eski dindar olma yolları üzerinde çalışmaları gerektiği argümanıdır (Oser, Scarlett ve Bucher, 2006). Ancak bu görüşler bilimsel olarak ispatlanamamış ve bilimsel olarak ispatlanamayan görüşler de bilim alanının dışında kabul edildiğinden geçerli sayılmamıştır.

Gelişim ve eğitim bilimleri alanında yaptığı çalışmalar konusunda şüphesiz en önemli isim Jean Piaget (1896-1980)'dir. Piaget ve onun araştırma yöntemlerini kullananlar gelişimi, bilişsel bir bakış açısıyla ele almıştır. Piaget'den hareketle bu yöntemleri dini gelişim ve din eğitimine uygulayan pek çok çalışma yapılmıştır. ${ }^{1}$ Bu çalışmaların neredeyse tamamı, dini gelişimi gözlemlenebilir ve ölçülebilir bilişsel süreçlerle açıklamaya çalışmış, ancak dinin ilahi ve aşkın yönünü büyük oranda ihmal etmişlerdir. Bu yaklaşımın doğal sonucu dini düşünceyi basitten karmaşığa doğru ilerleyen bir yapı olarak ele almak ve düşüncenin ilk nüvelerini ölçülemediği ve gözlemlenemediği için ihmal etmek veya görmezden gelmek şeklinde olmuştur.

Piaget'nin dini gelişim hakkında gerçekte ne düşündüğü konusu biraz kapalıdır. Bu sorunun cevabını araştırdığımızda aslında bir ironi ile karşılaşıyoruz. Çünküi Piaget sonrası çalışmaların ona yüklediği anlam hiç de Piaget'nin gerçek fikirleri değildir. Sanılanın aksine Piaget, Tanrı'ya nasıl inanılabileceği konusu ile çok fazla ilgilenmiştir. Otuzlu yaşlarına kadar Tanrı ile ilgili birçok araştırma yapan Piaget, bu araştırmaları sırasında aşkın ve içkin Tanrı arasında bir ayrım yapmıştır. Piaget başlangıçta muhafazakâr teolojinin yasaları takip edilmesi gereken aşkın ve gizemli bir Tanrı fikrini kabul ederken daha sonraları içkin bir Tanrı fikrine yönelmiştir. İçkinlik lehine aşkınlığı reddeden Piaget, Tanrı'yı kalpte, aklın normlarıyla ve İsa'nın içselleştirilmiş örneğiyle özdeşleştirmeye başlamıştır. Böylece Piaget'nin dini gelişim modeli, ilahiliğin aşkın anlamından içkin anlamalara dönüşüm etrafında yoğunlaşmıştır. Bu dönüşüm bilişsel bir değişimden çok daha fazlasını ifade ediyordu. Onun bu modelinde akıl vardı ama aynı zamanda kalp ve inanç da vardı (Oser, Scarlett ve Bucher, 2006). Başka bir deyişle, Piaget'nin Tanrı fikri bilişsel süreçler ve akıldan daha fazlasıyla ilgiliydi. Piaget 1929'da İsviçre Hıristiyan Öğrenciler Derneği üyelerine verdiği bir konferansta bunu açıkça ortaya koyuyordu (Vidal, 1987, s.287).

"Nesilden nesile yayılan düşünce akımları incelenirse, içkinlik, Tanrı kavramının tarihini karakterize eden manevileşme dürtüsünün devamı olarak görünür. Aynı 
ilerleme, ilkel dinlerin yarı-maddi Tanrısından metafizik Tanrıya olduğu gibi, doğaüstü nedensellik ile donatılmış aşkın Tanrıdan içkin deneyimin saf tinsel Tanrısına doğru gerçekleşir. Şimdi -ve asıl nokta budur- zeka alanındaki bu ilerleme, ahlaki ve toplumsal bir ilerlemeye, yani nihayetinde içsel yaşamın özgürleşmesine tekabül eder."

Din eğitiminin bilimsel bir yöntemle ele alınması konusundaki öncülügüüe rağmen Piaget'nin dini gelişim konusundaki görüşlerini eleştirel bir şekilde inceleyen ve onun bu konu üzerinde özellikle durmadığını belirten çalışmalar da vardır. Örneğin Piaget'nin dini arayışını inceleyen Fernardo Vidal (1987), onun dini ve manevi gelişim teorisini uygulama ve test etme konusunda bir program geliştirmediğini ifade eder. Piaget (2015), hayatının ilerleyen yıllarında ise bazı eserlerinde bu yönde bazı ipuçları verse de, doğrudan dini gelişim çalışmalarını uyguladığı bir örneğe rastlanmamaktadır. Ayrıca Piaget'nin özellikle oldukça zengin ve üretken bir şekilde geliştirdiği içkin ve kalbi bir Tanrı fikrini neden test etmediğini bilmememize rağmen onun bu yaklaşımının biliş ve zekâdan daha fazlasını ifade ettiğini belirtmemiz gerekir.

Piaget'nin çalışmaları hem eğitim bilimlerini hem de dini gelişim ve din eğitimi araştırmalarını oldukça etkilemiştir. Gelişimsel din eğitiminin ilk sistematik çalışmaları daha çok Piaget'nin metodolojisini kullanarak bunu din eğitimi ile ilişkilendirme şeklinde olmuştur. Ancak bu çalışmalar, bilimsel yöntemler kullanılarak özellikle Hıristiyan Avrupa'da geleneksel din eğitimine önemli eleştiriler getirmekte ve ayrıca tepki ile karşılanmakta idi. Piaget'nin araştırma metodolojisi, dini bilginin aktarılmasının artık yeterli olmadığını, bunların bilimsel olarak incelenmesi gerektiğini göstermiştir. Buna göre genel eğitimde olduğu gibi, din eğitiminde de, dini bilgi sistematik bir şekilde düzenlenmeli, aktarılmalı, tartışılmalı, eleştirilmeli, anlaşılıp anlaşılmadiğı test edilmeli, geri bildirimler değerlendirilmeli ve anlaşılmayan dini bilgiler gelişimsel olarak ertelenmelidir. Ne var ki bu bakış açısı ilk anda kulağa çok hoş gelmekle birlikte, Smart'ın (1968) sistematiğinde belirttiği gibi, dinin kutsallık boyutunun ne olacağı ile ilgili bir boşluk oluşturuyordu. Nitekim Piaget'ci bakış açısına en önemli eleştiri de bu konuda yapılacaktır.

Gelişim psikolojisi çalışmalarında Piaget'nin etkisi kadar önemli bir etki geliştiren başka bir isim ise Erik Erikson (1902-1994)'dur. Dini ve manevi gelişim ile ilgili 'temel güven' ve 'kimlik' üzerinde duran Erikson, dini gelişimin temeline güveni yerleştirir. Ancak Erikson'un bahsettiği ve 0-2 yaş

Çocuk ve Medeniyet 2021/2 döneminde geliştiğini iddia ettiği temel güven, bakım verene ve nihayetinde Yaratıcıya yönelik gelişen güvenden daha fazlasıdır. Burada Erikson'un (1963) güven ile kastettiği şey, hayatı yaşamaya değer kılacak bir evrene 
güvendir. Bu da kimlik gelişimini destekler. Ona göre din, hayatının her döneminde kişinin kimlik kazanmasında önemli bir rol oynar. Erikson, dinin insan hayatında gerçekleştirdiği pozitif değişimi ve kimlik kazanma sürecini önemli eseri Young Man Luther'de ayrıntılı bir şekilde inceler.

Erikson'un, gelişimi hayatın bir dönemi ile sınırlandırmayarak bu süreci kişisel bir kimliğe ulaşma çerçevesinde ele almasıyla ve dini kimlik kazanma yollarından biri olarak görmesiyle birlikte dini gelişim çalışmalarında önemli bir gelişme kaydedilmiştir. Nitekim onun hem gelişimin hem de dini gelişimin temelini kişinin kendisine, çevresine, anlamlı bir yaşam sürmek için bir evrene ve nihayetinde Yaratıcıya duyulan güven ile açılaması ve bunun gelişimsel olarak yaşam boyu sürdügünü ifade etmesi dini gelişim çalışmalarına yön vermiştir.

Dini gelişim çalışmaları konusunda en önemli çalışmalar Hümanist psikolojinin önemli temsilcilerinden biri olan Gordon Allport (18971967)'tan gelmiştir. Allport'un, olgunlaşmış dindarlık kavramı bu alanda, özellikle psikoloji disiplini içerisinde dini anlama, açıklama ve gelişimsel olarak ele almada en önemli girişimlerden birisi olmuştur. Olgunlaşmamış veya olgunlaşmış kişilik çalışmaları bir süre sonra benzer bir şekilde Allport tarafından dini gelişim ile ilişkilendirilmiştir. Ona göre olgunlaşmış dini yaşam, belirli kriterler gerektirir ve bunlar birçok tecrübe sonucunda gelişir. Buna göre dini konuları temyiz etme, olgunlaşmış dindarlığın en önemli özelliğidir. Burada inanç oldukça detaylı bir şekilde ayrıma tabi tutulur. $\mathrm{Bu}$, inancın her türlü eleştiri ve kritiğe açık olmasını gerektiren en önemli niteliktir. Buna göre kişinin kendi inancı ile ilgili her türlü eleştiriye açık olması olgunlaşmış dindarlığın temel özelliğidir. O halde olgunlaşmış dindarlıkta radikal hareketlere yer yoktur. Bunun için en önemli gelişim özelliği çocukluk dindarlığının terkedilmesidir. Ahlaki tutarlılık, evrensellik ve birleştirici karakter olgunlaşmış dindarlığın temel özellikleridir (Allport, 1962). Buna göre olgunlaşmış dindarlık kişinin çocuklukta edindiklerine sürekli yeni tecrübeler katması ve bunun sonucunda olgun kişilik gelişimine paralel olarak dindarlığın da niteliğinde gerçekleşen bir değişim gerektirir.

Allport (1962) bu çerçevede içe dönük ve dışadönük olmak üzere iki tür dindarlık biçimini gündeme getirir. Allport, kişilik gelişimi için kullandığı kavramların birçoğunu dini gelişim için de kullanmıştır. Ona göre dini his kişinin bütün varlığı ile ilişkilidir. Bu birbirine zıt iki tavır şeklinde ortaya çıkar. Bunlar dışa dönük (extrinsic) dindarlık ve içe dönük (intrinsic) dindarlıktır. Dışsal dindarlık daha ziyade çocuklukta gelişen ve biraz da çıkar ilişkisine dayanan bir nitelik gösterir. Dua ya da ibadet daha çok kişiye sağlayacağı dışsal fayda ile ilişkilidir. İçsel dindarlıkta ise, dışsal 
dindarlıktan tamamen farklı olarak, kişi yaşamının anlamını dinde ve kendi kişiliğinin bir parçası haline getirdiği maneviyatta bulur. Olgun dindarlık da diyebileceğimiz bu dindarlık şeklinde kişi, dini hayatın canlı bir olgusu olarak yaşama çabası içerisindedir. Bu yaşam dişsal bir çıkar, beklenti veya meta ile ilişkili değil yaratıcı ile kurulan samimi ve canlı bir ilişki ile gelişir. Özellikle gençlik döneminde din kişiliğin bir parçası haline gelerek, fonksiyonel otonomi özelliğini icra eder, böylece dindarlık içsel dindarlık haline gelir.

Söz konusu çalışmalar, hem gelişim dönemlerine göre ayrı din eğitimi müfredatlarının hazırlanması hem de içeriklerin yaş dönemlerine göre düzenlenmesi bakımında önemli bir temel oluşturmuştur (Benson, Donahue ve Erickson, 1993). Dini gelişimi sadece patolojik davranışlarla ilişkilendiren bazı yaklaşımların aksine bu çalışmalar dini, kimlik ve kişilik gelişimine katkısı açısından inceleyerek gelişimsel bir bakış açısı kazandırmıştır. Yukarıda kısaca dini, gelişimsel olarak inceleyen ve dinin kişisel gelişim süreçlerine yaptığı olumlu katkılara işaret eden kişiler ve çalışmalar incelenmiştir. Psikoloji ve eğitim bilimlerinin önemli temsilcileri ve sözünü ettiğimiz görüşleri daha sonra birçok araştırmaya da konu olacaktır. Bu çalışmalar sağlıklı bir din eğitimi için önemli bir temel teşkil eder. Hatta gelişim psikolojisi araştırmaları dini bilginin anlamlandırılıp içselleştirilmesi ve tercihlere yön vermesi için yaşanabilir ve saf bir dindarlığın gelişiminde önemli veriler sağlar.

\section{Gelişimsel Din Eğitimine Doğru: Metodoloji ve Prensipler}

Gelişimsel din eğitimi, '.. dine yönelik düşünme etkinliğini ifade etmenin kısaltılmış bir biçimidir.' (Goldman, 1964, s.3) şeklindeki bir argümandan hareket eder. Bu bakış açısı gelişim, eğitim ve din eğitimi süreçlerini bir bütün olarak ele alır. Öte taraftan bu bakış açısı, dini gelişim ve din eğitimini gelişimin ve eğitimin doğal bir parçası olarak görür ve bunu daha ileri bir düzeye taşımak üzere din ve maneviyata tamamlayıcı bir rol atfeder. $\mathrm{Bu}$ çerçevede gelişimsel din eğitimi çalışmalarının bazı temel prensipleri vardır. Bu prensipler aşağıdaki şekilde özetlenebilir:

\section{Bireyin gelişim özelliklerini göz ardı eden bir din eğitimi düşünüilmez}

Din eğitimi genel eğitime bir alternatif değildir. Aksine gelişimin ve genel eğitimin doğal bir yönünü temsil eder. Bu yönüyle gelişim psikolojisi 
çalışmalarındaki veriler sağlıklı bir din eğitimi için de dayanak oluşturur. Dini gelişim bireyin doğuştan sahip olduğu bazı temel yetenekleri diğer gelişim alanlarına paralel olarak geliştirme çabası şeklinde de değerlendirilebilir. Kimlik edinme, öz-yeterlilik kazanma ve sağlıklı bir kişilik geliştirme konuları başta Erikson olmak üzere, birçok psikoloğun üzerinde ısrarla durduğu bir konudur. Aynı durumun dini gelişim ile ilgili bir süreci var mıdır? Dini bir kimlik edinme, dini öz-yeterlilik kazanma ve kişilik geliştirme konusunda dini gelişim çalışmalarının yeri nedir? Ne olmalıdır?

Gelişim psikolojisi araştırmaları insanın doğuştan bir dizi doğal eğilime sahip olduğu düşüncesinden hareket eder. Gelişimsel din eğitimi de kişinin bu eğilimlerinden yola çıkarak, kutsallık hissini veya fitratını bulması konusunda kişiyi destekler. Genel olarak toplumun büyük bir kısmı inançlarını hazır bulur, aile ve çevresinin tesiriyle bunları benimsemeye başlar. Bununla birlikte insanların bir kısmı da ilerleyen yaşlarda inanç konularını sorgulayarak bunları kendi iradesiyle seçer veya reddeder. $\mathrm{Bu}$ bakımdan özellikle çocukların doğuştan sahip oldukları doğal yetenekleri keşfetmesine ve yaratılış özelliklerini gerçekleştirmesine fursat vermek gerekir. Nitekim bu sürecin sağlıklı bir şekilde atlatılması, sağlıklı bir dini kimliğin inşası açısından fevkalade önemlidir. Ancak bu Rousseau (2019)'nun belirttiği çerçevede çocuğun hiçbir şekilde gençlik dönemine kadar dini bir öğreti ile karşılaşmaması anlamında değil, her gelişim döneminde farklı bir metot ve içerikle inancın bir şekilde kişinin hayatında olması ile ilgili bir durumdur.

\section{Din eğitiminin metot ve içeriğini belirlemede gelişimsel basamaklar esas alınir}

Piaget'nin gelişimi dört basamak şeklinde sınıflandırması, kendisinden sonra bu alanda yapılan bütün çalışmaları etkilemiştir (Schweitzer, 2006). Piaget'nin sınıflandırması, zihinsel gelişimin en basit düzeyden soyut işlemler düzeyine evrildiği, her bir basamağın bir önceki basamak üzerinde geliştiği ve nihayetinde hipotetik düşünce ile zirveye ulaştığ ilerleme modeline dayanır. Bu gelişim modelinde, her yaş döneminin bazı gelişim görevleri vardır ve kişi bu dönemlerdeki gelişim görevlerini sağladığında bir sonraki dönemdeki gelişim görevlerine geçebilir. Tıpkı bir merdivenin basamaklarını tırmanmak gibi, kişi aşama aşama mesafe kateder ve nihayetinde her dönemin gelişim görevlerini tamamlayarak bir ilerleme gösterir.

Piaget'nin metodolojisi kısa süre içerisinde dini gelişim ve din eğitimi çalışmalarına da uyarlanmıştır (Bkz. Hyde, 1990). Bu çalışmalar dini 
gelişim özelliklerini açığa çıkarma, bu gelişimsel özelliklere göre bir din eğitimi müfredatı hazırlama ve bunları test etmeyi merkeze almıştır. Ancak bu çalışmalar daha sonra sosyal gelişim ve ahlaki gelişim kuramlarını da göz önünde bulundurarak farklı boyutlara taşınmıştır. Örneğin psikolog Fritz Oser ve teolog Paul Gmünder'in dini yargı gelişimi teorisi, dini bilginin Tanrı ile girilen özel bir ilişki şekliyle geliştiğini iddiasından ve genel gelişim teorilerinin birçoğunun verilerinden hareketle dini yargı gelişim basamakları ortaya koymuştur. Örneğin özerk olmayan dini yönelim ve almak için vermek yönelimi bütünüyle erken çocukluk ve çocukluk dönemi bilişsel, duygusal ve ahlaki gelişim özelliklerini gösterir (Oser ve Gmünder, 1991). Bu dönemdeki çocuklar için Tanrı, iyilikleri ödüllendirir ve kötülükleri cezalandırır. Müslüman çocuklarda yapılan çalışmalarda da benzer bulgulara ulaşılmıştır (Yavuz, 2012; Coles, 1990). Bu gelişim döneminde Allport'un belirttiği dışa dönük dindarlık özellikleri ön plandadır.

\section{Din eğitiminde içerikten çok yöntem üzerinde odaklanılır}

Gelişimsel din eğitimi doğası itibariyle eğitim bilimleri verilerini temele alır ve bu konuda öğretim yöntemini öncelikli bir mesele olarak görür. 'Küçük çocuklar sadece kendilerine öğretilen dini değil, öğretilme şeklini de öğrenirler.' (Lee, 1988, s.186). Bunun sebebi eğitim bilimleri açısından öğretme yöntemlerinin daha kalıcı olmasıdır. Dinin öğretilme şekli ile ergenlik ve yetişkinlikteki inanç gelişimi arasında güçlü bir ilişki vardır. Buna göre katı, kuralcı ve sadece 'yap' veya 'yapma' şeklindeki dini eğitim, Tanrı tasavvurunu da etkilemekte ve katı bir dini görüş gelişimi ile devam etmektedir.

Çocukluk dönemi din eğitimi, bu çerçevede doğrudan bilgi aktarımı veya kurallar sisteminden ziyade ilgi uyandırma şeklinde anlaşılır. Din eğitimi bir metnin literal olarak aktarımı şeklinde mi olmalı yoksa, canlı bir olgu olarak çocukların hayatına dokunan, hissedilen ve düşünceyi geliştiren bir olgu mu olmalıdır? Gelişimsel din eğitiminde bu problem 'Kutsal metni öğretmek mi?’ yoksa 'Kutsal metinden öğrenmek mi?' şeklinde bir ayrıma gidilerek çözülmeye çalışılır (Goldman, 1971, s.71). Buna göre çok erken yaşlardan itibaren sadece metne dayalı bir öğretim, özü itibariyle yetişkinlere hitap eden bir kitabın anlaşılmasını problemli hale getirir. İslam dini açısından düşünüldügüünde bu 'Kur'an'dan öğretmek' şeklinde sistematize edilebilir. Buna göre çocukların dil gelişimleri, tecrübeleri ve zihinsel gelişimleri de dikkate alınarak Kur'an'a ilgi duymaları sağlanır. Bu durumda Kur'an, çocukların anlamakta zorlanmayacakları kıssaların ve ahlaki öğütlerin kendisini sunduğu canlı bir kaynağa dönüşür. 


\section{Din eğitiminde bireysel hazırbulunuşluk esastır}

Çocukların, yetişkinlerin küçültülmüş bir modeli olduğu şeklindeki anlayışın gelişimsel olarak bir karşılığı yoktur. Buna göre çocuk bütün özellikleriyle kendine özgü bir bireydir ve sadece yetişkinlerin sahip olduğu yetenek ve yeterliliklerin tamamına sahip değildir. Bu sebeple çocukların hazırbulunuşluk durumunu gözetmek özellikle din eğitimi açısından zorunludur. Din eğitiminde şu soruları sormak gerekir (Cox, 1966, s.84): Bu basamaktaki bir çocuk için hangisi yahut ne tür bir dini anlayış mümkündür? Bir sonraki basamak için ne tür tecrübe ve zihni yetenekler gerekir? Ne tür bir eğitim-öğretim yöntemi çocuğun içinde bulunduğu basamağa hitap eder ve bir sonraki basamağa geçiş sağlayabilir?

Eğitim, kişinin hazırbulunuşluğu ile ilgili bir temel oluşturur. İyi bir öğretmen de uygun zamanı gözeterek çocukların öğretime esas olan konularda bazı ön bilgiler edinmesini sağlar. Hazırbulunuşluk özellikle dini açıdan gelişimin temel özelliklerinden biridir. Dini konularda bir bilgiyi almak üzere hazır bir duruma gelmeyen bir öğrenciye sadece dini kaygılarla öğretim gerçekleştirmek başarısızlıkla sonuçlanacağı gibi sonraki dönemlerde ortaya çıkacak bazı problemlere de zemin oluşturur. Dinden uzaklaşma yahut radikalleşme bunun muhtemel sonuçlarından bazılarıdır.

\section{Din eğitimi eleştirel bir pedagojik yaklaşım benimser}

Gelişimsel din eğitiminde temel kavramlardan biri ‘merak'tır. Özellikle çocukluk döneminde herhangi bir konu üzerinde konuşma başlatmak ve bu konuyu bütün yönleri ile tartışabilmek, başta dini düşünce olmak üzere diğer gelişim alanlarına katkıda bulunur. Salt bir dini bilgi aktarımının çocuklarda uzun süreli ve kalıcı bir etki sağlamadığı açıktır. Öte taraftan bu tür aktarımların tartışmaya açık olmaması da bazı olumsuz sonuçlar doğurur ki bu durum bizi endoktrinasyon problemi ile karşı karşıya getirir.

Endoktrinasyon (katiyen eleştiri ve tartışma kabul etmeyen bir öğretim şekli) modern eğitimin ve din eğitiminin çözmesi gereken temel problemlerden biridir. Endoktrinasyon içeriğin tartışmalı konumunu, içeriğin sözde doğru olduğu sunumuyla öğrenenden gizlenmesidir. Burada içerik rasyonel olarak tartışılmaz ve mutlak doğru olarak sunulur (Hull, 2004). Gelişimsel din eğitimi temelde endoktrinasyonu reddeder ve eğitimde tartışılmayan hiçbir konunun olmadığını, bu tartışmanın da özü itibariyle dine aykırılık taşımadığını, daha ziyade yerindelik anlamında olması gerektiğini varsayar. Örneğin herhangi bir Kur'an kıssası eğer çocuklar tarafından tam olarak anlaşılmıyor ise, bu durumda; (a) kıssanın 
içeriğini çocuğun anlayacağı bir şekilde çocuk diline aktarma, (b) bazı bölümleri anlaşılmıyor ise bu bölümleri yaşamın ileri dönemlerine erteleme, (c) çocukların gelişim düzeylerine uygun değilse bütünüyle çocukluk döneminde kıssayı kullanmama şeklinde seçenekler sunar. Bunu çocuğun kıssa ile ilgili sorması muhtemel bütün soruları göz önünde bulundurarak ve eleştirel bir yaklaşımla incelemeyi hesaba katarak düzenlemek gerekir.

\section{Din eğitimi yaşam boyu devam eden bir faaliyetidir}

Gelişim psikolojisi araştırmaları gelişimin yaşam boyu devam ettiğini, buna göre eğitimin de yaşam boyu sürmesi gerektiğini göstermiştir (Santrock, 2009). Gelişim psikolojisi çalışmalarında Erikson'un ayrıntılı bir şekilde ifade ettiği ve sistemleştirdiği yaşam boyu gelişimde, her dönem ayrı bir öneme sahiptir. Buna göre her gelişim döneminin kendine özgü gelişim görevleri, krizleri ve mutlaka karşılanması gereken ihtiyaçları vardır (Erikson, 1968). Bu yargı dini gelişim sahasında da geçerlidir. Birçok çalışma özellikle çocukluk ve ergenlik dönemi üzerinde yoğunlaşır. Dindarlığı doğrudan çocukluk ile ilişkilendiren çalışmalar olmakla birlikte (Copley, 2008), her gelişim döneminin kendine özgü bir dindarlığının olduğunu iddia eden gelişim psikolojisi çalışmaları da vardır (Allport, 1962). Buna göre her gelişim dönemi bir önceki gelişim döneminin devamı, aynı zamanda önceki dönemin kazanımlarının yeniden yorumlanarak ileri bir aşamaya geçilmesi anlamına gelir. Çocukluk döneminde kazanılan dini alışkanlıklar, ergenlik dönemi için fevkalade önemlidir, ancak bu kazanımların ergenlik döneminde değişmesi gerekir. Çünkü ergenlik soyut düşüncenin geliştiği yeni bir dönemdir. Aile ve çevrenin etkisi ile gelişen dini kazanımların ergenlik döneminde olgun ve kendine özgü bir dindarlık şekline evrilmesi beklenir. Gelişimsel olarak bu süreç yaşamın her dönemi için böyle devam eder. Kısaca inanç her gelişim aşamasında kendisini yeniden var eder. Bu durum her gelişim dönemi için bir din eğitimi yaklaşımını gerektirir.

\section{Gelişimsel din eğitimi yaşam merkezlidir}

Program geliştirmede birçok farklı yaklaşım söz konusudur. Bunlar içerisinde konuyu, metni ve öğrenciyi merkeze alan yaklaşımlar mevcuttur. Gelişimsel din eğitimi doğrudan öğrenciyi merkeze alır, konu ve metin de öğrencinin durumuna göre belirlenir. Burada çocukların gelişimine uygun olmayan bir müfredat temelden reddedilir. Bu anlamda gelişimsel din eğitimi çözümü gelişim psikolojisi verilerinde bulmaya çalışır. Buna göre psikoloji dini gerçeklik veya dini düşünceyi ispatlamak için bir bakış açısı 
geliştirmez. Fakat daha önemli bir şey kazandırır: Kişinin dini düşünce geliştirmesinde ve dindarlığa uygun koşulların sağlanmasında bir yöntem geliştirmek üzere kıymetli veriler sağlar.

Çocuklar ergenlik dönemine kadar gerçek anlamda dini bir düşünceye sahip olamazlar. Çünkü çocukların tecrübe ve zihinsel gelişim faaliyetleri bu konuda yeterli değildir. Ancak bu durum erken çocukluk ve çocukluk döneminde çocukların dinden tamamen habersiz oldukları anlamına da gelmez (Ashton, 2000). Bu açıdan din eğitimi, teolojiyi değil pedagojiyi öncelemelidir. Çocuğun merkezde olduğu ve dinin de bu çerçevede çocuğun anlayış düzeyine göre sunulduğu bir yaklaşım esas alınır. Bu süreçte çocuğun günlük yaşamında karşılığı olan konular din eğitiminin hareket noktası olarak kabul edilir. Sevgi, Allah'tan önce çevredekilere karşı gelişmeli, Allah'a güvenden önce kardeşine güven gelişmeli, Allah ile iletişime geçmeden bitkilerle, hayvanlarla iletişim sağlanmalıdır. Somut olgulara karşı gelişen duygu ve düşünceler bu sayede Allah'a bir yol bulabilmelidir. Böylece inançtan tamamen yoksun bir çocukluk değil, yaşayan canlı bir olgu olarak yaşamla iç içe bir inanç gelişimi söz konusu olur.

\section{Gelişimsel Din Eğitimine Yönelik Eleştiriler}

Farklı gelişim kuramları kişinin belli bazı evrelerden geçtiğini, kültürden kültüre bazı farklılıklar olmakla beraber bunların benzerlikler taşıdığını ifade eder. Dini gelişim çalışmalarında da benzer bir metodoloji takip edilmiştir. Buna göre her yaş döneminin bazı özellikleri vardır ve bu dönemlerin gelişim özelliklerine uygun bir içerik ve yöntemle din eğitimi yapılmalıdır. Bu çerçevede geliştirilen birçok eğitim ve din eğitimi yaklaşımı farklı açılardan eleştirilmiştir. Bu eleştiriler bazı başlıklar altında şöylece incelenebilir:

\section{Gelişim dönemlerinin evrenselliği}

Bazı araştırmacılar yaş, dönem veya basamak şeklindeki sınıflandırmaların kişinin gerçek dini gelişim özelliklerini yansıtmayacağını ifade eder. Bu çalışmalarda kişinin gerçekte algılama ve öğrenme kapasitesi yaş veya herhangi bir gelişim dönemi ile ilgili değildir. Kişinin deneyimlerinin derinliği çoğu kez sözel olarak ifade edilenlerin çok ötesindedir ve bu durum kişinin bu deneyimleri yaşayamayacağı anlamına gelmez (Moltmann,

Çocuk ve Medeniyet 2021/2 2000). Hatta bazı yaklaşımlarda çocuklar ile yetişkinler arasında birçok ortak gelişim özelliği olduğu ve bunların aslında bu tür tecrübeler aracılığı ile daha da güçlendiği ifade edilir. Sadece gelişim dönemleri göz önünde 
bulundurularak yapılacak eğitimde bu ortak deneyimlerin birçoğunun ihmal edilme riski vardır (Boyatzis, 2011).

Piaget başta olmak üzere onun metodolojisini kullanan araştırmalarda, bilimsel araştırma yöntemlerinden kaynaklanan bazı sınırlılıklar vardır. Bu konuda gelişim psikoloğu Robert Slavin'in (2006, s.42) de ifade gibi, 'çocuklar Piaget'nin belirttiğinden daha donanımlı' olabilmekte ve bunu teyit eden araştırmalar yapılmaktadır. Hatta gelişim kuramlarının bir 'at gözlüğüne’ dönüşme riski söz konusudur (Miller-McLemore, 2006, s.656). Şöyle ki, 'bu dönemdeki çocuklar bunu anlar ama şunu anlamaz' şeklindeki bir bakış açısı bilişsel gelişim açısından bir problem teşkil etmemekle birlikte, din eğitimi açısından problem oluşturabilir. Bu konudaki bir kısım çalışmalarda çocukların tam bir bilim insanı şeklinde birçok konuyu anlayabildikleri, ancak bunu ifade etme konusunda bazı problemler yaşadığı belirtilmiştir (Schweitzer, 2006).

\section{Maneviyatın bilişsel gelişime feda edilmesi}

Dini gelişimin gözlemlenebilir, ölçülebilir ve test edilebilir olgulara indirgenmesi, eğitimde duyguların ve özellikle maneviyatın ihmal edilmesi sonucunu doğurduğu şeklinde bir eleştiriye sebep olmaktadır. Gelişimsel modelde bilişsel aktarım mümkündür, ancak Devries'in (2001, s.162) belirttiği gibi, "örneğin sevgi ve duygu aktarımı sözel değil, bilinç dışı bir deneyimle mümkündür.” Bu ise sadece bireysel bir çaba ile değil, diğerleri ile girilen uzun soluklu ilişkiler aracılığıyla öğrenilir ve yaşanır. Modern hayatta karşılaşılan birçok problem, kişinin sadece zihinsel yönünü geliştirmekle kalmaz, aynı zamanda diğer insanlar ve canlılarla kurulan ilişkiler aracılığıyla aşılır.

Gelişimsel din eğitimine en önemli eleştiriyi getiren din eğitimcisi John M. Hull, sadece bilişsel, sosyal ve ahlaki gelişim ekseninde gerçekleştirilecek bir din eğitiminin günümüz çocuklarını, karşılaşmaları pek muhtemel olan bazı problemlerden uzaklaştıramayacağını ifade eder. Buna göre sadece sosyal yönden eğitilen çocuklar toplumu, aileyi ve bunların ilişkisini öğrenirler. Ahlak eğitiminde ise doğruyu, yanlışı, ahlaki düzeni öğrenirler. Hull'e (2002) göre bunların hiçbiri günümüz çocuğunun karşılaşması muhtemel problemlerine çözüm olamaz. Örneğin şiddet, çocuğun baş etmesi gereken bir problemdir ve manevi eğitim çocuğa yüksek insani nitelikler kazandırarak bu problemleri aşması için yardım eder. Maneviyat, insani yönü ortaya çıkarır ve diğerleriyle yardımlaşmaya dayalı bir hayat yaşamada destek sağlar. Çıkara dayalı ilişkilerin sıradanlaştırdığı bir yaşam içerisinde ilişki ve manevi bir yönelim geliştirme kişiyi hayata hazırlar. 


\section{3. İnanç gelişiminin karmaşık yapısının ihmal edilmesi}

Gelişim kuramlarının metodolojisini kullanan dini gelişim ve din eğitimi kuramcıları inancın zihinsel gelişim veya ahlak gelişiminde olduğu gibi bir gelişim seyrinde ilerlediğini ortaya koymuştur. Bu çalışmalar inancın kendine ait karmaşık ve iç içe geçen yönünün görmezden gelindiğini ifade eder. Bu durumda şöyle bir soru ile karşı karşıya gelinir: Acaba inanç yaşa bağlı olarak sürekli gelişen ve belli bir noktada da zirve yapan bir olgu mudur?

Bu soru dini gelişim alanındaki çalışmalarda farklı şekillerde cevaplanmaya çalışılmıştır. Bilişsel, sosyal ve ahlak gelişim kuramcılarının metodolojisini dini gelişime aktaran kuramcılar, büyük oranda inancın benzer süreçler geçirdiğini ifade etmiştir. Aynı şekilde gelişim teorileri içerisinde katı evreler yerine esnek gelişim modelleri öneren çalışmalar da mevcuttur (Reich, 1997). Ancak bu teoriler, temelde gelişimsel bir modele dayanmakta ve inancı kısmen ahlak gelişimine indirgemekten kurtulamamaktadırlar.

İnanç gelişimini farklı bir bakış açısıyla ele alan John H. Westerhoff (2000), hiyerarşik bir inanç yerine farklı bir model önerir. Buna göre inancın dört boyutu vardır ve bunlar arasında bir geçiş söz konusudur. İnançta bir önceki düzeyden yeni bir düzeye geçişte daha önceki inanç özellikleri yok olmaz ve yok sayılamaz. Çünkü kişi bir sonraki düzeyde iken önceki yaşantıları hayatından kolayca çıkaramaz. Bu durum zincire sürekli yeni halkalar eklemek gibidir. Zincire yeni halka eklemek eskilerini çıkarmayı gerektirmez. Hayatımızda sürekli bir şekilde inanca bazı yeni unsurlar ekleriz, yine hayatımızın bazı dönemlerinde zincirin en başındaki halkaya tekrar döneriz. İnanç döngüsel olarak böyle bir dinamizm içerisinde devam eder. Bu da düşüncenin, hislerin ve iradenin aktif bir niteliğe sahip olduğunu gösterir. Kişi bazen daha önceki inanca aykırı davranabilir, bu stres ve kriz yaratabilir. Alternatifler öğrenildikçe ve tecrübe edildikçe, sorgulamalar daha anlamlı hale gelir ve inancın dinamizmi de buradan kaynaklanır.

Her ne kadar İslam tasavvuf kültüründe, çalışmamızın başında değindiğimiz üzere hiyerarşik bir sistem öngörülse de, bu durum inancın sürekli gelişim halinde olduğu ve doğrusal olarak hep ilerleme gösterdiği anlamına gelmez. Kur'an-1 Kerim'de inancın sürekli değişkenlik gösteren yapısına vurgu yapılır. Bazı faaliyetlerin imanı arttırdığı ifade edilir (Enfâl Sûresi, 8/2). Bu bakımdan Kur'an'da doğrusal bir artıştan ziyade, zamansal olarak değişken ve dinamik bir sürece işaret edilir. Peygamberlerin şüphelerinden bahsedilir 
ve bu şüphelere gerekçe olarak kalbin mutmain olması ifade edilir (Bakara Sûresi, 2/260).

Gelişimsel olarak örneğin Allport'un dışa dönük dindarlığının yaşın ilerlemesiyle içe dönük dindarlığa evrildiğini gösteren bir kanıt yoktur. Böyle bir dönüşüm çocuklukta olabileceği gibi ergenlikte de yetişkinlikte de olabilmektedir. Örneğin kişi hayatında hiçbir şekilde içe dönük bir dindarlığı tecrübe etmeyebilir veya Fowler (1991)'in de ifade ettiği ve inanç gelişiminin zirvesine yerleştirdiği evrensel inanç, bir çocukta gelişebilmekte iken diğerlerinde hiçbir şekilde gerçekleşmeyebilir. Aynı şekilde Goldman'ın (1964; 1971) belirttiği soyut dini düşünce çocukluk döneminde kazanılabileceği gibi, birçok kişide yaşam boyu kazanılamaz. Bu durum inancın karmaşık yapısından kaynaklanır. Kişi Piaget'nin belirttiği sınıflandırmada somut işlemlerden soyut işlemlere geçebilir ve bunun belli yaş aralıklarında gerçekleşmesi pek tabi ki mümkündür. Ancak inanç söz konusu olduğunda, böyle bir geçiş ve ilerleme pek mümkün görünmemektedir.

\section{Sonuç}

Sistematik olarak Rousseau ile başlayan ve daha sonra Hall'in çalışmalarıyla bilimsel incelemelere konu olan dini gelişim meselesi gelişim psikolojisinin öncü ismi olan Piaget ile zirve yapmıştır. Piaget sonrası çalışmalar, din ve maneviyatın bilimsel ölçütlere göre incelenebilmesinin yolunu açacaktır. Buna göre dini bilgi, öğrencileri merkeze alan bir eğitim bilimsel bakış açısıyla geliştirilebilir, test edilebilir, uygulanabilir. Daha da önemlisi geri bildirimlerden hareketle içerik ve yöntem yeniden düzenlenebilir. Bütün bunlar eğitim bilimleri alanındaki gelişmelerin dini gelişim ve din eğitimine uyarlanmasıyla gelişimsel bir din eğitimi yaklaşımının yolunu açmıştır. Bu süreç özellikle Hıristiyan Avrupa kültüründe Kilisenin faaliyetlerine bir reaksiyon olarak da algılanmıştır. Ancak bunlar bir bütünlük içerisinde incelendiğinde, Rousseau gibi bazı örnekler istisna edilecek olursa, her gelişim döneminin bazı dini ve manevi özellikler taşıdığını ve din veya maneviyatı göz ardı edecek bir eğitim anlayışının mümkün olmadığını belirtmişlerdir.

Gelişimsel din eğitimi temelde herhangi bir gelişim döneminde din ve maneviyatın olması veya olmaması ile ilgili bir konuyu tartışmaz. Buradaki

Çocuk ve Medeniyet 2021/2 temel problem, her bir gelişim dönemini bütün özellikleriyle bilmek, buna göre dini bir içerik geliştirmek ve metodolojiyi de gelişim özelliklerine göre uygulamaktır. Bu anlamda özellikle yöntem konusu bu bakış açısının 
temel hareket noktasını oluşturur. Buna göre eğitimde öğretme yönteminin çoğu kez içerikten daha kalıcı olduğu varsayılır. Bu sebeple çocuğun hazırbulunuşluk düzeyine uygun, onun zihinsel, sosyal ve duygusal gelişimi esas alınarak bir içeriğin hazırlanması gerekir. Gelişimsel yöntem, bilginin bir dogma olarak sunumunu reddeder. Bunun yerine karşılıklı etkileşim ile dini bilgi çocukla birlikte yeniden yapılandırılır. Bunu da yaşam merkezli bir din eğitimi yaklaşımı çerçevesinde gerçekleştirir. Buna göre sağlıklı bir din eğitimi yaklaşımında çocuğun gelişim dönemi, ilgileri, merakları, bireysel farklılıkları, kültürel arka planı gibi hususlar bilinmeli ve öğretim yöntemi buna göre düzenlenmelidir. Bunun için bir din eğitimcisinin teolojiden önce iyi bir psikoloji ve pedagoji bilgi ve kültürüne sahip olması gerekmektedir.

Gelişim psikolojisindeki birçok kuram hem kısa sürede uygulamaya kavuşmuş hem de bazı yönleri ile eleştirilere konu olmuştur. Gelişimsel din eğitimi çalışmaları da bu süreçten etkilenmiştir. Nitekim gelişim kuramlarına yapılan eleştirilerin neredeyse tamamı dini gelişim ve din eğitimi kuramlarına da yöneltilmiştir. Gelişim dönemlerinin evrenselliği meselesi gelişim psikolojisinde çokça tartışılan bir konudur. Mesele din ve maneviyat olunca, konu daha karmaşık bir vaziyet almaktadır. Gelişim dönemlerine bağlı bir din eğitiminin maneviyatı dışlayacağı şeklinde ortaya atılan eleştiriler gelişimsel din eğitimin salt bilgi aktarımından öteye geçemeyeceğini, dinin önemli bir yönünü oluşturan maneviyat ve kutsallığı geliştiremeyeceğini ileri sürmüşlerdir. İnanç biliş veya duygular gibi gelişir mi, yoksa inancın kendine ait karmaşık yapısı döngüsel bir nitelik mi gösterir sorusu burada yanıt bulmamaktadır.

Dini gelişim ve eğitim genel gelişimin dışında bir alan değil, onun doğal bir parçasıdır. Bu sebeple dini gelişim ve eğitim, genel gelişimin bir boyutu olarak bilimsel anlamda incelenmektedir. Çalışmamız içerisinde görüşlerini incelediğimiz Piaget, Erikson, Allport gibi kuramcıların dışında, dini bazı patolojik davranışlarla ilişkilendiren kuramcılar da vardır. Burada özellikle bilimsel ölçütler çerçevesinde hareket eden görüşler ele alınmış, modern dönemlerde inanç konularının, çocuğun hayatında nasıl ve hangi içerikle yer alması gerektiği konusu üzerinde durulmuştur. Burada objektiflik, eleştiri ve yaşamla bağ kurma kritik üç kavram olarak karşımıza çıkmaktadır. Bu kavramlar aynı zamanda geleceğin din eğitiminin de temel kavramları olmak durumundadir. 


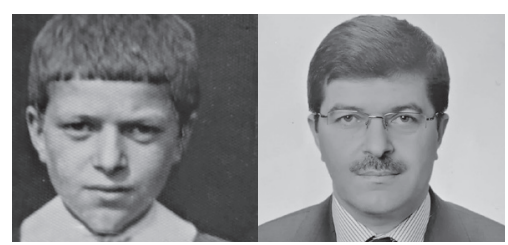

\section{Mustafa Köylü}

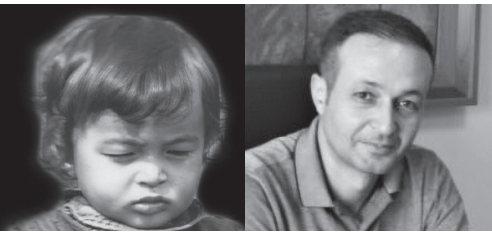

\section{Cemil Oruc}

\section{Kaynakça}

Allport, G. W. (1962). The individual and his religion-A psychological interpretation. New York: The Macmillan Company.

Arasteh, A. R. ve Sheikh, E. A. (2015). Tasavvuf: Evrensel benliḡe giden yol. K. Sayar (Yayına Haz.). Sufi psikolojisi: Bilgeliḡin ruhu, ruhun bilgeliḡi içinde (ss. 53-96). İstanbul: Timaș Yayınları.

Ashton, E. (2000). Religious education in the early years - Teaching and learning in the first three years of school. London: Routledge.

Atik, A. (2019). Çocukluk dönemi din eḡitimine bilimsel temelli bir yaklașım denemesi. Dini Araștırmalar, 22(56), 353-369.

Benson, P. L., Donahue, M. J., ve Erickson, J. A. (1993). The faith maturity scale: Conceptualization, measurement, and empirical validation. Research in the Social Scientific Study of Religion, 5, 1-26.

Boyatzis, C. J. (2011). Agency, voice, and maturity in children's religious and spiritual development. S.B. Ridgely (Ed.). The study of children in religions: A methods handbook içinde (ss. 19-32). London: New York University Press.

Boyatzis, C. J. (2014). Spiritual development during childhood and adolescence. L.J. Miller (Ed). The Oxford handbook of Psychology and spirituality içinde (ss. 151-164). Oxford: Oxford University Press.

Coles, R. (1990). The spiritual life of children - The inner lives of children. Boston: Houghton Mifflin Company.

Copley, T. (2008). Teaching religion - Sixty years of religious education in England and Wales. Devon: University of Exeter Press.

Cox, E. (1966). Changing aims in religious education. London: Routledge and Kegan Paul.

Devries, D. (2001). Towards a theology of childhood. Interpretation, 55(2), 161-173.

Elkind, D. (1970). The origins of religion in the child. Review of religious research, 12(1), 35-42.

Erikson, E. H. (1963). Childhood and society. New York: Norton\&Company Inc.,

Erikson, E. H. (1968). Identity youth and crisis. New York: W.W. Norton \& Company.

Fowler, J. W. (1991). Weaving the new creation - Stages of faith and the public church. New York: HarperCollins. 
Gazali, M. (2004), İhya-u ulumi'd-din. Beyrut: Darussadr.

Goldman, R. (1964). Religious thinking from childhood to adolescence. London: Routledge and Kegan Paul.

Goldman, R. (1971). Readiness for religion: A basis for developmental religious education. New York: Seabury Press.

Hull, J. M. (2002). Spiritual development: Interpretations and applications. British Journal of Religious Education, 24(3), 171-182.

Hull, J. M. (2004). Practical theology and religious education in a pluralistic Europe. British Journal of Religious Education, 26(1), 7-19.

Hyde, K. E., (1990). Religion in childhood and adolescence: A comprehensive review of the research. Birmingham, Alabama: Religious Education Press

Lee, J. M. (1988). How to teach: Foundations, processes, procedures. D. Ratcliff (ed.). Handbook of preschool religious education içinde (ss. 152-223). Birmingham, Alabama: Religious Education Press.

Meadow, M. J. (1992). Personality maturity and Teresa's interior castle. Pastoral Psychology, 40(5), 293-302.

Miller-McLemore, B. (2006). Children and religion in the public square: "Too dangerous and too safe, too difficult and too silly. The Journal of Religion, 86(3), 385-401.

Moltmann, J. (2000). Child and childhood as metaphors of hope. Theology Today, 56, 592-603.

Oser, F. ve Gmünder, P. (1991). Religious judgement - A developmental approach. Birmingham, Alabama: Religious Education Press.

Oser, F. K., Scarlett, W. G. ve Bucher, A. (2006). Religious and spiritual development throughout the life span. R. M. Lerner (Ed.). Handbook of child psychology-Volume I. theoretical models of human development içinde (ss. 942-998). New Jersey: John Wiley \& Sons, Inc.

Piaget, J. (2015). Judgment and reasoning in the child. London: Routledge.

Reich, K. H. (1997). Integrating differing theories: The case of religious development. B. Spilka ve D. N. McIntosh (eds.). The psychology of religion - Theoretical approaches içinde (ss. 105-113). Oxford: Westview Press.

Rousseau, J. J. (2019). Emile. Ankara: Türkiye İș Bankası Kültür Yayınları.

Santrock, J. W. (2009). Life-span development. Boston: McGraw-Hill.

Schweitzer, F. (2006). Children as theologians: god-talk with children, developmental psychology, and inter-religious education. D. Bates vd. (Ed.). Education, religion and society: Essays in honour of John M. Hull içinde. London: Routledge.

Slavin, R. E. (2006). Educational psychology: Theory and practice. Boston: Pearson.

Smart, N. (1968). Secular education - The logic of religion. London: Faber and Faber.

Vidal, F. (1987). Jean Piaget and the liberal Protestant tradition. M. Ash ve W. Woodward (Ed.). Psychology in twentieth-century thought and society içinde (ss. 271-294). London: Cambridge University Press.

Westerhoff, J. H. (2000). Will our children have faith?. Toronto: Morehouse Publishing.

Wright, R. (1953). The outsider. New York: Harper \& Row.

Yavuz, K. (2012). Çocukta dinî duygu ve düșüncenin gelișimi. İstanbul: Boḡaziçi Yay. 